\title{
ПОСТЮГОСЛАВСКОЕ ПРОСТРАНСТВО: КОНФЛИКТ И ВНЕШНЕЕ ПРИНУЖДЕНИЕ К МИРУ В БОСНИИ И ГЕРЦЕГОВИНЕ
}

\author{
Ю. Э. ДЕМЬЯНОВИЧ \\ Белорусский государственный университет, \\ Минск, Республика Беларусь
}

\begin{abstract}
Аннотация. В статье рассмотрен процесс участия внешних акторов в урегулировании конфликта в Боснии и Герцеговине (БиГ) в 1992-1995 гг., который являлся наиболее сложным из всех конфликтов, возникших в результате разрушения Социалистической Федеративной Республики Югославия (СФРЮ). Жесткое противостояние трех основных этнических групп БиГ (боснийский сербов, боснийских мусульман и боснийских хорватов) лишало постюгославское государство возможности найти внутренние источники выхода из кризиса. На начальном этапе его эскалации, до 1994 г., роль медиатора конфликта взяли на себя Европейское сообщество (EC) и ряд международных организаций, однако их усилия оказались безуспешными. Конфликт в БиГ требовал поиска новых методов для югославского урегулирования. Новые подходы возникли вместе с проявлением стремления Соединенных Штатов Америки (США) использовать боснийский конфликт как мусульманскую карту для укрепления своих сверхдержавных позиций. США решили воспользоваться согласием Совета Безопасности Организации Объединенных Наций на использование военных сил Североатлантического Альянса (HАТО) для принуждения сторон к миру. Это позволило Вашингтону пресечь вооруженную конфронтацию враждующих сторон силовым воздействием: принуждением враждующих сторон к миру. Конфликтующие стороны были вынуждены сесть за стол переговоров, в результате чего были заключены Дейтонские соглашения, которые изменили геополитическую ситуацию на постюгославском пространстве.
\end{abstract}

Ключевые слова: Босния и Герцеговина; ООН; Европейское сообщество; США; боснийский конфликт; принуждение к миру; Дейтонские соглашения.

Образец цитирования: Демьянович Ю. Э. Постюгославское пространство: конфликт и внешнее принуждение к миру в Боснии и Герцеговине // Актуальные проблемы международных отношений и глобального развития: сб. науч. ст. Минск, 2021. Вып. 9. С. 54-69. https://doi.org/10.33581/2311-9470-2021-9-54-69 
Введение. В силу чрезвычайной этно-религиозной дифференциации Босния и Герцеговина в процессе своего административнотерриториального устройства оказалась самым сложным постюгославским государством. Эскалация противостояния на этой почве приобрела исключительно кровопролитный характер. Только в первой половине 1993 г. Совет Безопасности (СБ) ООН принял 5 резолюций по проблеме боснийского урегулирования. Их множественность свидетельствовала о безрезультатности медиации и предопределила трансформацию подходов к урегулированию. Фактически СБ ООН дал согласие любой международной организации применить силу на территории БиГ с целью прекращения кровопролития. Урегулирование ситуации в БиГ пережило два этапа внешнего воздействия. Первый завершился очевидной констатацией, что не срабатывают мирные призывы, а санкции, налагаемые $\mathrm{OOH}$, неэффективны. На втором этапе Запад пошел на силовое принуждение враждующих сторон к миру - беспрецедентную меру, не применяемую в Европе после Второй мировой войны. Вашингтон инициировал военную интервенцию НАТО, которая пресекла вооруженное этнополитическое противостояние в БиГ. Заключение Дейтонских соглашений 1995 г. перекроило геополитическую ситуацию на постюгославском пространстве.

В русскоязычной исследовательской литературе данные аспекты освещены крайне фрагментарно, а западная заметно грешит односторонним обвинением сербов в эскалации противостояния и одобрением мер против них. В силу изложенных обстоятельств цель статьи сформулировать объективные оценки конфликта и внешнего принуждения к миру в БиГ. Исследовательской задачей определены изменения, произошедшие в боснийском конфликте с включением в югославское урегулирование США. Хронологические рамки статьи охватывают 1992-1995 гг. Объектом исследования выступают конфликты в постсоциалистической Югославии, предметом - урегулирование боснийского кризиса.

Методы исследования. Для раскрытия темы использованы общенаучные, специально-исторические методы, а также методы из теории международных отношений. Общенаучные методы (анализ, синтез, индукция, дедукция, аналогия, сравнение, обобщение) позволили проанализировать роль и динамику участия ЕС и США в конфликте и эволюцию боснийского кризиса в зависимости от их действий. Историко-описательный метод, как вид специальноисторических методов, применен для реконструкции событий в БиГ и 
Хорватии, вызванных внутренними конфликтами и внешним вмешательством. Анализ ситуации (наблюдение), как метод теории международных отношений, позволил проследить на основе изученных документов событийную последовательность эскалации конфликтов в БиГ и в Хорватии.

Обзор литературы по теме. Для написания данной статьи использованы труды русскоязычных и зарубежных историков, политиков и специалистов-международников, раскрывающие переговорный процесс в ходе югославских конфликтов и операции НАТО в БиГ. В русскоязычной литературе тема переговоров в югославских конфликтах отображена слабо. Поэтому акцент сделан на использование документов системы ООН и разработок западных специалистов. В частности, освещены подходы при раскрытии темы таких авторов, как W. Bert (В. Берт) [1], F. Carr (Ф. Карp) [2], S. Touval (С. Туваль) [3], M. Ragazzi (М. Рагацци) [4], Е. О’Balance (Э. О’Баланс) [5], D. Anderson (Д. Андерсон) [6], S. Burg (С. Бург) [7], V. K. Aggarwal (В. К. Аггарвал) [8], P. W. Galbraith (П. В. Гэлбрейт) [9], R. Belloni (Р. Беллони) [10], J. А. Tirpak (Дж.А. Тирпак) [11].

Особое значение для написания статьи имели работы В. Берта [1], Ф. Карра [2], С. Туваля [3], Э. О’Баланс [5], С. Бурга [7] и П. В. Гэлбрейта [9], что позволило выявить проблемы переговорного процесса, роль США в нем и значение операции НАТО для прекращения вооруженного конфликта как в БиГ, так и в Хорватии.

Просматривающийся нередко односторонний подход западных авторов к оценке роли США в балканских конфликтах и операции НАТО в БиГ верифицировался анализом документом и трактовкой фактов и событий в статьях российских исследователей А. С. Киясова [12] и В. И. Бажукова [13]. Так, А. С. Киясов [12] доказывает, что вмешательство США в конфликт нельзя трактовать как сугубо гуманное и гуманитарное, поскольку эта страна преследовала собственные цели. В свою очередь, В.И, Бажуков делает акцент на отрицательных сторонах операции НАТО в БиГ.

Результаты исследования. Миротворческий процесс в БиГ прошел два ключевых этапа: с преобладающим участием Европейского сообщества и без участия США - на начальном этапе урегулирования конфликта и с преобладающим участием США - на втором этапе. Изначально США стояли в стороне от вмешательства в югославский кризис, справедливо полагая его европейским делом. Длительное время Вашингтон не определял свою позицию, предоставляя 
Европейскому сообществу роль основного медиатора по югославским вопросам. Для такой позиции имелись основания. В начале 1990-х гг. администрация США столкнулась с целым рядом первоочередных проблем более масштабного характера, требующих оперативных решений в сжатых временных рамках. К ним следует отнести распад СССР, войны в Персидском заливе, проблему расползания ядерного оружия на постсоветском пространстве и глобальное позиционирование США в новом мировом порядке.

В этой цепи проблем фактор СФРЮ для США был малозначительным. Администрация США решила занять позицию наблюдателя, позволив $\mathrm{EC}^{1}$ возложить на себя все полномочия по урегулированию [1, с. 127; 2, с. 92]. В роли лидера миротворческого процесса Европейское сообщество пребывало до 1994 г. - до момента вступления в него США, к которым автоматически перешла эта роль [3, с. 103]. В то же время нельзя сказать, что подобные изменения стали внезапными, скорее они носили характер постепенного вовлечения.

По-настоящему ход миротворческого процесса европейские медиаторы определяли в конфликтах в Словении и Хорватии. При этом реальных возможностей для урегулирования им хватило лишь для Словении, где отсутствовало столкновение противостоящих сил на религиозно-этнической почве. В Хорватии, где данный фактор возник в полную силу, европейская медиация была вынуждена обратиться к ООН за помощью [3, с. 39-47]. В результате миротворчество привело к замораживанию конфликта на несколько лет.

На очередном витке постюгославского противостояния - в ситуации, сложившейся в БиГ, где этно-религиозный фактор оказался острее, чем в Хорватии - ЕС и ООН оказались в крайне затруднительном положении. Во-первых, обе организации изначально были стеснены в имеющихся в их распоряжении методах. Во-вторых, в отличие от Хорватии и Словении, где ЕС мог выбирать средства урегулирования, в БиГ подобная свобода маневра, кроме сложности ситуации, ограничилась еще одним существенным фактором: обозначившейся заинтересованностью США. И хотя интерес к БиГ не был первоочередным в перечне международных приоритетов США, однако в отличие от Словении и Хорватии он все же проявился. Это заключалось в том, что к этому времени Вашингтон активно укреплял влияние в Персидском заливе. Для реализации эффективной стратегии

\footnotetext{
${ }^{1}$ До 1993 г. Европейское сообщество именовалось как Европейские сообщества, однако аббревиатура ЕС присуща обоим названиям.
} 
ему было важно поддерживать дружественные отношения с мусульманским миром, который стоял на стороне боснийских мусульман.

Так, поддержку боснийских мусульман особо демонстрировала Турция, для которой Балканы - традиционная сфера влияния. Более того, часть населения этой страны имела боснийские корни. Даже по этой причине США не могли отстраниться от боснийского урегулирования, ибо отношения с Турцией для них имели особый приоритет как со страной - членом НАТО и важным союзником в войне США с Ираком [3, с. 138-139].

Проявившаяся активность США в БиГ еще больше затруднила деятельность европейских медиаторов. Боснийские мусульмане, надеясь на американскую поддержку, не шли на компромиссы и придерживались жесткой позиции, требуя сохранения БиГ в качестве унитарного централизованного государства, что противоречило этнорелигиозным реалиям республики и острой межэтнической и межконфессиональной вражде между сербской, хорватской и мусульманской общинами [3, с. 137-138]. Примером такого поведения мусульман стали события вокруг Лиссабонской международной конференции по Боснии и Герцеговине, проходившей в 1992 г. На конференции переговоры велись в русле создания особого административного деления БиГ. Итогом могло стать установление мира путем создания кантонов на основе учета национальных, исторических, религиозных, экономических и географических критериев [3, с. 107-110; 12, с. 250]. Также, стороны договорились о создании трех кантонов, однако вскоре после окончания конференции лидер мусульман Алия Изетбегович отказался от этого плана [3, с. 107-110]. Не исключено, что на его демарш повлияли проявившиеся американские симпатии к боснийским мусульманам.

В результате приемлемое решение боснийской проблемы было сорвано. Тем не менее, несмотря на неурегулированные этнические проблемы, весной 1992 г. международное сообщество признало БиГ как независимое государство. Подчеркнем: несмотря на несоответствие критериям признания, одобренным европейскими странами. Это произошло потому, что на признании настаивали США. Фактически, признание БиГ со стороны ЕС состоялось в обмен на признание Вашингтоном Хорватии [2, с. 93; 3, с. 138]. Данная ситуация привела к тому, что ЕС утратили все прежние рычаги влияния на мусульманскую общину БиГ [3, с. 111]. Кроме этого, признание ожида- 
емо вылилось в полноценную войну между сербской и мусульманской общинами [3, с. 112-114].

Одновременно ЕС постарались создать новые рычаги обуздания конфликта. Совместно с ООН 26 августа 1992 г. была созвана Лондонская конференция по бывшей Югославии. Планировалось, что конференция будет работать до полного урегулирования югославских проблем. В этой связи был сформирован постоянный орган: Координационный штаб конференции в Женеве под сопредседательством ЕС и ООН [3, с. 112-114; 4, с. 1527-1537].

Лондонская конференция из-за неуступчивости сторон конфликта не смогла привести БиГ к миру. В то же время нельзя говорить о ее бесполезности: конференция создала новые каналы коммуникации, а также подготовила предварительные планы устройства БиГ: план Венса-Оуэна, план Оуэна-Столтенберга, план Европейского сообщества [3, с. 115-118]. Но первоначально ни один из планов не оказался применимым к БиГ из-за сохранения разногласий между сторонами конфликта, европейскими странами - медиаторами, а также из-за все возрастающего интереса США к протеканию боснийского кризиса [3, с. 117-118, с. 130].

Рост интереса США закономерно прослеживался во все большем вовлечении НАТО в боснийское противоборство. Изначально продекларированной целью Североатлантического альянса во всех югославских конфликтах было недопущение потери роли лидера в вопросе европейской безопасности [3, с. 141-143]. Для этого, с учетом трансформации мировой политической системы, была принята новая стратегическая концепция $\mathrm{HATO}^{2}$, допускавшая для Альянса возможность осуществления превентивной дипломатии и кризисного урегулирования [2, с. 120].

Концепция касалась мировой ситуации в целом, а не конкретного локального противостояния. Тем не менее, она открыла для НАТО путь к участию в урегулировании постюгославских конфликтов. Опираясь на новую концепцию, в июне 1992 г. Североатлантический совет заявляет о готовности поддерживать миротворческую деятельность под эгидой ОБСЕ ${ }^{3}[2$, с. 120]. В декабре 1992 г. похожее заяв-

\footnotetext{
${ }^{2}$ The Alliance's New Strategic Concept // North Atlantic Treaty Organization. [Electronic resourse]. 2008. URL: https://www.nato.int/cps/en/natohq/official_texts_23847.htm. (accessed: 11.09.2020).

${ }^{3}$ Final Communique of the Ministerial Meeting of the North Atlantic Council // North Atlantic Treaty Organization [Electronic resource]. 2008. URL: https://www.nato.int/cps/en/natohq/ official_texts_23983.htm. (accessed: 11.09.2020).
} 
ление прозвучало в отношении операций под эгидой ООН. Особо подчеркивалось, что содействие НАТО возможно только под эгидой, но никак не самостоятельно ${ }^{4}$ [2, с. 120]. В период с 1992 по 1994 гг. участие НАТО протекало в форме мониторинга. Сначала это выражалось в отслеживании порядка соблюдения эмбарго на поставки вооружения и морских операций в Адриатике на соответствие Адриатическому соглашению, затем - в мониторинге зон безопасности в БиГ и бесполетной зоны ${ }^{5}$ [2, с. 122-124]. Несмотря на явно ограниченное вовлечение в урегулирование конфликта, само присутствие НАТО свидетельствовало об особом внимании США к БиГ. Эскалация американского интереса вела к тому, что ограниченные механизмы урегулирования ЕС и $\mathrm{OOH}$ в зоне конфликта еще больше сузились, и это превращало участие США в медиативном процессе из гипотетической возможности в необходимость.

Включение США в конфликт ознаменовало начало второго этапа югославского урегулирования. Оно происходило в условиях формирования нового переговорного формата: Контактной группы. Вашингтон не скрывал свою позицию защитника прав мусульман. Такая ситуация была проигрышной в дипломатическом отношении. В этой связи обозначилась целесообразность привлечения России, традиционного гаранта интересов сербов. Без подобного дипломатического равновесия в глазах сербского населения проамериканский формат выглядел бы явно ангажированным и без перспективы на успех. Акцептация конфликтующими сторонами Контактной группы стала возможной только благодаря участию в ней двух внешних акторов единовременно.

Нельзя сказать, что оба внешних актора обладали одинаковым влиянием в Группе: США мгновенно заняли лидирующую позицию, в то время как Россия, в тот период ослабленная после крушения СССР, за откровенное лидерство не боролась.

Однако вмешательство США в конфликт также привело к смене американского взгляда на постконфликтное устройство БиГ: в интересах миротворческого процесса Вашингтон принял идею устройства Боснии и Герцеговины по национальному признаку, хотя ранее, не-

\footnotetext{
${ }^{4}$ Final communique of the Ministerial meeting of the North Atlantic Council // North Atlantic Treaty Organization [Electronic resource]. 2008. URL: https://www.nato.int/cps/en/natohq/official_ texts_23972.htm. (accessed: 11.09.2020).

${ }^{5}$ NATO's role in Bosnia and Herzegovina // North Atlantic Treaty Organization [Electronic resource]. 2008. URL: https://www.nato.int/docu/comm/1999/9904-wsh/pres-eng/06bosn.pdf. (accessed: 01.09.2020).
} 
смотря на активное проталкивание данной идеи ЕC, ведущие американские политические круги считали, что такое устройство приведет к нежизнеспособности БиГ.

На фоне переоценки внутренней ситуации в БиГ произошел перелом в балканской внешней политике США: от простого наблюдения за ситуацией до непосредственного участия и лидерства в процессе урегулирования. К слову: активное вмешательство США в боснийский кризис без прихода к власти администрации Билла Клинтона и корреляции ее взглядов на свой внешнеполитический курс было бы невозможно [3, с. 122-123]. Именно новая команда приняла решение вмешаться в югославский конфликт в качестве посредника. В качестве нового механизма югославского урегулирования в рамках Контактной группы впервые под давлением США стала рассматриваться возможность принуждения воюющих сторон к миру путем использования против них военной силы. Предполагалось использование авиаударов со стороны НАТО.

Помимо этого, Вашингтон активно требовал снятия эмбарго с поставок вооружения сторонам конфликта в БиГ. Позиция оправдывалась несправедливостью распределения вооружения между общинами. В частности, Хорватия помогала боснийским хорватам, а боснийские сербы вооружались из запасов Югославской Народной армии (ЮНА), также периодически получали помощь из Сербии и Черногории. Наиболее пострадавшей стороной от эмбарго выглядели боснийские мусульмане.

Идеи авиаударов, снятия эмбарго и прямого вмешательства США в конфликт стали ключевыми для Б. Клинтона и его аппарата, хотя и до него подобные предложения циркулировали в американском истеблишменте, но отвергались как излишне затратные, непопулярные, невыгодные для США и потенциально ведущие к увязанию страны в чужом конфликте.

Администрация Клинтона активно настаивала на данных подходах. Но им препятствовал ЕС: главным образом, в лице Франции и Великобритании. Европейские страны полагали, что поставки вооружения приведут к эскалации насилия, а вмешательство НАТО активизирует российскую поддержку Сербии, следовательно, вызовет массовые жертвы среди миротворцев, представленных формированиями из граждан стран ЕС [1, с. 175-176; 2, с. 94-95; 3, с. 141-143; 14, с. 26]. Контактная группа искала приемлемую развязку в рамках дипломатических переговоров. 
Противодействие ЕС и пересмотр американской концепции постконфликтного устройства БиГ потребовали от США генерирования варианта достижения хорватско-мусульманского сотрудничества в БиГ. Результатом стал проект создания хорватско-боснийской федерации, которая консолидировала две из трех конфликтующих сторон и внесла ряд значительных изменений в ход боснийской кампании ${ }^{6}$.

Во-первых, федерация частично разрешала вопросы территориально-административного деления (по крайней мере, между боснийскими хорватами и мусульманами). Во-вторых, она приближала соседнюю независимую Хорватию к сотрудничеству не только с боснийскими хорватами, но и мусульманами, поскольку проблемы БиГ увязывались с решением проблемы Хорватии, претендовавшей на реинтеграцию хорватских территорий [3, с. 137-140]. В-третьих, решался вопрос поставок вооружения для мусульман, при этом эмбарго не снималось. В-четвертых, обозначилась возможность «малой крови» при проведении вероятной военной операции. Теперь за счет действий сухопутной армии мусульман и хорватов НАТО могла лишь ограничиться авиаударами. А ранее именно неизбежная (и непопулярная) вероятность проведения наземной операции останавливала членов НАТО от начала операции. В действительности, начиная с 1992 г., Альянс к ней готовился, хотя странами - членами она воспринималась как крайняя мера, и отношение к ней было в целом отрицательным [3, с. 141-143].

Как упоминалось выше, в период с 1992 по 1994 гг. НАТО ограничивала свое посредничество в конфликте мониторингом и консультациями. А как только Б. Клинтон стал президентом США, полномочия НАТО стали значительно расширяться [1, с. 165; 2, с. 122-124]. Наиболее ярким примером этого служит американская инициатива принятия резолюции 836 Совета безопасности ООН от 4 июня 1993 г. $^{7}$, легализовавшей использование сил НАТО под эгидой ООН для урегулирования боснийского конфликта [2, с. 122-124; 5, с. 140].

После принятия резолюции последовали первые угрозы НАТО об использовании авиаударов. Подобная ситуация возникла в феврале 1994 г. как ответ на теракт на рынке в Сараево. Виновниками произошедшего были признаны боснийские сербы. Соответственно, им

\footnotetext{
${ }^{6}$ Framework Agreement for the Federation (Washington Agreement) // UNITED NATIONS Peacemaker [Electronic resource]. 2019. URL: https://peacemaker.un.org/sites/peacemaker.un.org/ files/BA_940301_FrameworkAgreementOnTheFederation.pdf. (accessed: 11.09.2020).

${ }^{7}$ Resolution 836 (1993) // United Nations [Electronic resource]. 2020. URL: https://undocs.org/ S/RES/836(1993). (accessed: 11.09.2020).
} 
Брюссель предъявил ультиматум о передаче позиций и тяжелого вооружения Силам ООН. За невыполнение ультиматума НАТО грозила авиаударами. По данному вопросу ООН была солидарна с НАТО [6, с. 16-17; 7, с. 286-287]. Это фактически создало международноправовой прецедент и закрепило позиции НАТО в конфликте [2, с. 124-125; 3, с. 143]. В то же время, несмотря на явную трансформацию роли НАТО в боснийском конфликте, развертывание операции затянулось на 2 года. Во многом это произошло из-за разногласий ЕС и США в вопросах формата участия НАТО. ЕС до последнего выступал против операции Североатлантического Альянса, ссылаясь на то, что на территории БиГ нет американских наземных войск. Ситуация подсказывала, что США, в отличие от ЕС, практически не понесет человеческих жертв в случае наземной операции [3, с. 141-143; 14, с. 2526]. В то же время без наземного сопровождения авиаудары теряли свою эффективность.

В этой связи США рассматривали два варианта операции:

- использование наземных сил США. Данная идея до последнего отвергалась, поскольку ставила под угрозу жизни американских граждан и грозила недовольством населения США;

- использование в операции НАТО боснийских хорватов и мусульман против боснийских сербов. Данный план стал реальным, как только хорваты и мусульмане смогли прийти в марте 1994 г. к решению о создании федерации. Также данный план требовал участия Хорватии, поскольку без ее реального участия невозможно было создать ни боснийскую федерацию, ни осуществить наземную поддержку [3, с. 144-147].

Хорватия пошла на эти шаги, поскольку взамен рассчитывала на помощь в реинтеграции отдельных частей своей территории, а также она все еще сохраняла враждебность к сербам. Вопрос наземной поддержки был разрешен, хотя ЕС продолжало возражать, опасаясь за жизни своих миротворцев. Опасения в целом были преодолены к декабрю 1994 г., когда администрация Б. Клинтона предложила решение: если авиаудары НАТО вызовут необходимость эвакуации миротворцев Европейского сообщества, то США пришлют и разместят свои наземные войска для помощи их вывода и обеспечения безопасности [3, с. 141-143].

Вслед за этим Генеральный секретарь НАТО 30 марта 1995 г. во вступительном слове на саммите Североатлантического совета не исключил вероятности вывода «голубых касок» ООН из зоны босний- 
ского конфликта в крайней необходимости. Формальным поводом для заявления послужили случаи взятия в заложники и убийства миротворцев, а также бомбардировки зон безопасности ${ }^{8}$.

Итогом преодоления разногласий становится достигнутое в июле 1995 г. решение НАТО на проведение операции [3, с. 147].

Параллельно - в процессе переговоров в рамках Контактной группы - достижение согласия о создании боснийско-хорватской федерации вело к определенной результативности усилий переговорщиков. Так, 13 мая 1994 г. на первой встрече Контактной группы на министерском уровне было подписано соглашение о совместной работе участников для прекращения огня и установления мира. Соглашение увязывало положения о снятии санкций с Союзной Республики Югославия с принятием сербами предложений группы. Исходя из взаимоусиления позиций мусульман и хорватов, Контактная группа разработала новый план территориального устройства БиГ, увеличив долю территории мусульман в Восточной Боснии, что автоматически сокращало сербский коридор к городу Брчко [3, с. 128].

Это было выгодно Хорватии и мусульманам, но противоречило интересам сербов. Брчко являлся стратегически важной точкой коммуникаций: он давал доступ к мостам через р. Саву, разграничивающим БиГ и Хорватию. А ранее мосты связывали боснийских и хорватских сербов, помогавших друг другу в ведении боевых действий. Соответственно, боснийские сербы отказались от этого плана, но диалог не прекратили [3, с. 129; 7, с. 301-303]. Однако далее переговоры перестали быть равноправными ввиду сложившейся коалиции мусульман и хорватов, а также позиции Сербии, России, США и ЕС. Их целью стало давление на боснийских сербов [8, с. 107-108; 9 , c. 646].

В очередной раз обстановка стала крайне напряженной. Она накалилась еще больше в связи с артиллерийским обстрелом Сараево 28 августа 1995 г. Данный инцидент прекратил переговоры в рамках Контактной группы и стал поводом к операции НАТО «Обдуманная сила», начавшейся через 2 дня [3, с. 36]. Операция проводилась против боснийских сербов. Именно они были объявлены виновниками произошедшего на основании показаний миротворческого контингента ООН о том, что обстрел Сараево велся с позиций боснийских

\footnotetext{
${ }^{8}$ Secretary General's Opening Remarks to the NAC of 30 May 1995] // North Atlantic Treaty Organization [Electronic resourse]. 2008. URL: https://www.nato.int/cps/en/natohq/opinions_24786. htm?selectedLocale=en. (accessed: 11.09.2020).
} 
сербов ${ }^{9}$. Бомбардировка НАТО и поддержка ее авиаударов наземными силами хорватов и мусульман привели к быстрому завершению вооруженного противостояния как в БиГ, так и в Хорватии [10, с. 1516]. За период операции авиация НАТО уничтожила около 100 объектов, фактически ликвидировав военный потенциал боснийских сербов. Потери вынудили их отказаться от изначальных требований и начать переговоры о будущем БиГ [11, с. 36-38; 13, с. 38-40].

Операция НАТО в БиГ заставила хорватско-мусульманскую федерацию и боснийских сербов, а также Хорватию и хорватских сербов сесть за стол переговоров, которые велись при абсолютном лидерстве США, но с использованием механизмов Контактной группы [3, с. 148]. Результатом стало заключение двух соглашений: Дейтонского для БиГ ${ }^{10}$ и Эрдутского для Хорватии. 5 декабря 1995 г. ${ }^{11}$ Североатлантический совет заявил о прекращении военных действий в бывшей Югославии ${ }^{12}$.

Обсуждение полученных результатов. Проведенное исследование позволяет разделить миротворческую деятельность 19921995 гг. в постюгославских государствах на два отдельных этапа: первый - лидерство ЕС в миротворческом процессе и второй - лидерство США. При этом резких смен лидеров не происходило; изменения в целом происходили эволюционно.

ЕС обладал и смог воспользоваться всеми возможностями принятия решений в Словении, несколько утратил свободу действий в Хорватии из-за острых препятствий этно-религиозного характера. Вследствие чего Евросоюз был вынужден прибегнуть к более активному миротворчеству в рамках ООН. Все же организация утратила рычаги урегулирования в конфликте боснийских сербов, хорватов и мусульман, поскольку в БиГ этно-религиозная ситуация оказалась сложнее, чем в Хорватии. Кроме этого, в игру включился влиятель-

\footnotetext{
${ }^{9}$ Statement by the Secretary General of NATO of 30 August 1995 // North Atlantic Treaty Organization [Electronic resource]. 2008. URL: https://www.nato.int/cps/en/natohq/opinions_24774. htm? selectedLocale=en. (accessed: 11.09.2020).

${ }^{10}$ Ceasefire Agreement for Bosnia and Herzegovina // United Nations Peacemaker [Electronic resource]. 2019. URL: https://peacemaker.un.org/sites/peacemaker.un.org/files/BA_951121_Dayton Agreement.pdf. (accessed: 11.09.2020).

${ }^{11}$ Ceasefire Agreement for Bosnia and Herzegovina // United Nations Peacemaker [Electronic resource]. 2019. URL: https://peacemaker.un.org/sites/peacemaker.un.org/files/BA_951121_Dayton Agreement.pdf. (accessed: 11.09.2020).

${ }^{12}$ Basic Agreement on the Region of Eastern Slavonia, Baranja and Western Sirmium (Erdut Agreement) // North Atlantic Treaty Organization [Electronic resourse]. 2008. URL: https://peacemaker.un.org/sites/peacemaker.un.org/files/HR_951112_ErdutAgreement.pdf. （accessed: 11.09.2020).
} 
ный внешнеполитический актор: заинтересованность в процессе урегулирования конфликта продемонстрировали США. Данный факт предопределил дальнейшее тесное переплетение интересов внешних сил и действий внутренних противников в процессе урегулирования кризиса в БиГ.

Хотя конфликт в БиГ разгорелся в 1992 г., вопрос внешнего лидерства в его урегулировании окончательно определился лишь в 1994 г. - с официальным вступлением в процесс США, сопровождаемым внедрением Контактной группы как механизма дипломатического урегулирования. До этого участие США претерпевала постепенную эволюцию: от мониторинга ситуации до полноценного участия в мирном урегулировании в качестве лидера переговорного процесса.

Смена роли США стала возможной с приходом к власти администрации Б. Клинтона и изменением взглядов о роли США в мире. Роль США оказалась сугубо двойственной. Их симпатии к мусульманам привели к утрате рычагов давления ЕС и ООН на БиГ, что привело к эскалации конфликта и бесконтрольности в управлении ситуацией. Но с другой стороны, США активизировали процесс военного принуждения к миру в БиГ, став основным адвокатом данной идеи на дипломатическом поле. Эта идея сопровождалась связкой с проектом федеративного устройства БиГ. Проект внедрялся явно сепаратистски, поскольку исключал участие боснийских сербов в оформлении федерации. Успех проекта привел к достижению перемирия между боснийскими хорватами и мусульманами. Это означало победу на дипломатическом фронте. Подключение к переговорам Хорватии усилило как ее позиции, так и роль федерации БиГ. Согласие Хорватии оплачивалось поддержкой США в вопросе реинтеграции хорватских земель.

Логика дипломатических шагов привела к созданию антисербской коалиции хорватов и мусульман. На арене постюгославского противостояния сербские общины Хорватии и БиГ остались в одиночестве. Но с учетом военного превосходства сербов в рамках Союзной Республики Югославия было проблематично заставить их сесть за стол переговоров, тем более вынудить пойти на уступки. В сложившейся ситуации США усматривали единственный вариант урегулирования: использование военных сил НАТО против сербов.

Организация операции по внешнему принуждению к миру заняла длительный срок, ибо оставались перманентные разногласия между ЕС и США из-за опасений европейцев понести собственные жерт- 
вы в ходе операции. Наконец, был найден повод к началу операции НАТО из-за факта обстрела Сараево. Операция позволила принудить сербские общины к миру. Возобновившаяся фаза переговоров после военных действий привела к согласию сербов пойти на компромиссы. Результатом стало относительное политическое урегулирование в БиГ и Хорватии.

Заключение. Урегулирование чрезвычайно сложной и конфликтной ситуации в молодых постюгославских государствах сопровождалось применением разнообразных форм и механизмов миротворчества: попытками достичь согласия между внутренними силами противодействия, созданием различных переговорных площадок под эгидой внешних акторов, а также таким беспрецедентным для Европы второй половины XX в. средством, как силовое принуждение к миру. Данные средства и меры стали возможны благодаря вступлению США в конфликт в качестве лидера переговорного процесса. При этом, несмотря на очевидный результат мер, инициированных Вашингтоном, (конфликты в БиГ и Хорватии были в основном урегулированы), отдельные вопросы их правомерности, нейтральности и гуманности остаются спорными.

\section{Библиографические ссылки}

1. Bert W. The Reluctant Superpower: United States's Policy in Bosnia, 1991--95 // New York: Macmillan Press, 1997. 296 p.

2. Carr F. NATO in the New European Order // New York: Macmillan Press, 1996. 192 p.

3. Touval S. Mediation in the Yugoslav Wars: The Critical Years, 1990-95 // New York: Palgrave Publishers Ltd, 2002. 211 p.

4. Ragazzi M. Conference on Yugoslavia arbitration commission: opinions and questions arising from the dissolution of Yugoslavia // International Legal Materials. 1992. Vol. 31. № 6. P. 14881548 .

5. O’Balance E. Civil War in Bosnia 1992-94 // New York: Macmillan Press, 1995. 291 p.

6. Anderson D. The collapse of Yugoslavia: Background and Summary // Parliament of Australia [Electronic resource]. 1996. URL: https://www.aph.gov.au/binaries/library/pubs/rp/1995-96/96 rp14.pdf (accessed: 20.02.2019).

7. Burg S. The War in Bosnia-Herzegovina: Ethnic Conflict and International Intervention. New York: Routledge, 2000. 499 p.

8. Aggarwal V. K. Institutional Designs for a Complex World: Bargaining, Linkages, and Nesting. New York: Cornell University Press, 1998. 240 p.

9. Galbraith P. W. Washington, Erdut and Dayton: Negotiating and Implementing Peace in Croatia and Bosnia Herzegovina // Cornell International Law Journal. 1997. Vol. 30. P. 643-649.

10. Belloni R. State building and international intervention in Bosnia. New York: Routledge, 2007. $212 \mathrm{p}$.

11. Tirpak J. A. Deliberate Force. AIR FORCE Magazine. 1997. Vol. 80. № 11. P. 35-43.

12. Киясов A. C. Политика «признания/непризнания»: американские интересы на Балканах на начальном этапе югославского кризиса (1991-1992 гг) // Ученые записки Казанского университета. Серия: Гуманитарные науки. 2010. Т. 152, кн. 3, ч. 1. С. 246-253. 
13. Бажуков В. И. «Миротворческая» операция НАТО в Боснии и Герцеговине (1992-1995): концепция и реальность // Управленческое консультирование. 2018. № 2. С. 34-41.

14. Daalder I. H. Decision to Intervene: How the War in Bosnia Ended // Foreign Service Journal. 1998. Vol. 73. P. 24-31.

Дата поступления статьи: 25.08.2021.

Автор: Демьянович Юлия Эдуардовна - аспирант кафедры международных отношений Белорусского государственного университета (Минск); e-mail: yuliya-dzemy@ rambler.ru.

\title{
THE SPACE OF POST-YUGOSLAVIA: CONFLICT AND EXTERNAL PRESSURE FOR PEACE IN BOSNIA AND HERZEGOVINA
}

\author{
YU. DZEMYANOVICH \\ Belarusian State University, Minsk, Republic of Belarus
}

\begin{abstract}
The process of participation of external actors in the conflict settlement in Bosnia and Herzegovina (BiH) in 1992-1995 is considered in the article. Bosnian case was the most difficult from all the Yugoslavian conflicts because of fierce confrontation between Bosnian Serbs, Bosnian Croats and Bosnian Muslims.

This situation made the European peace efforts unsuccessful. Despite this fact, the European Community with the help of certain international organizations held the role of main mediator until 1994.

Bosnian conflict asked world society to find new methods for Yugoslavian peace settlement. However, without the USA's participation it was impossible. The situation was changed in 1994 when USA's new administration showed a desire to use the Bosnian conflict as a Muslim map to strengthen its superpower positions.

In order to realize its plan the administration of President Bill Clinton used the accord of the UN Security Council to give any international organization the right of using force on the territory of $\mathrm{BiH}$ for the sake of ending the bloodshed. Taking advantage of this right, Washington initiated the NATO military intervention that stopped the armed ethnopolitical confrontation in $\mathrm{BiH}$. The settlement of the situation in $\mathrm{BiH}$ went through two stages of external influence. The first stage ended with the obvious assertion that peaceful appeals and imposing of UN sanctions did not work.

At the second stage, the West began to force the warring parties to peace. This measure had been unprecedented for Europe since the World War II. Washington managed to suppress the armed confrontation between the warring parties by force. The warring parties were forced to end war and begin peace conversations. As a result, the Dayton Agreements of 1995 were concluded. This treaty reshaped the geopolitical situation in the post-Yugoslav area.
\end{abstract}


Key words: Bosnia and Herzegovina; UN; European Community; USA; Bosnian conflict; peace enforcement; Dayton Accords.

For citations: Dem'janovich Ju. (2021). Postjugoslavskoe prostranstvo: konflikt i vneshnee prinuzhdenie k miru v Bosnii i Gercegovine [The space of Post-Yugoslavia: conflict and external pressure for peace in Boania and Herzegovina]. In: Actual problems of international relations and global development: collection of scientific papers. Minsk, Vol. 9, p. 54-69. https://doi.org/10.33581/2311-9470-2021-9-54-69

\section{References}

1. Bert W. (1997). The Reluctant Superpower: United States's Policy in Bosnia, 1991-95. New York: Macmillan Press, $296 \mathrm{p}$.

2. Carr F. (1996). NATO in the New European Order. New York: Macmillan Press, 192 p.

3. Touval S. (2002). Mediation in the Yugoslav Wars: The Critical Years, 1990-95. New York: Palgrave Publishers Ltd, $211 \mathrm{p}$.

4. Ragazzi M. (1992). Conference on Yugoslavia arbitration commission: opinions and questions arising from the dissolution of Yugoslavia. In: International Legal Materials. Vol. 31, No. 6, p. $1488-1548$.

5. O’Balance E. (1995). Civil War in Bosnia 1992-94. New York: Macmillan Press, 291 p.

6. Anderson D. (1995). The collapse of Yugoslavia: Background and Summary // Parliament of Australia [Electronic resource]. URL: https://www.aph.gov.au/binaries/library/pubs/rp/199596/96rp14.pdf (accessed: 20.02.2019).

7. Burg S. (2000). The War in Bosnia-Herzegovina: Ethnic Conflict and International Intervention. New York: Routledge, $499 \mathrm{p}$.

8. Aggarwal V. K. (1998). Institutional Designs for a Complex World: Bargaining, Linkages, and Nesting. New York: Cornell University Press, 240 p.

9. Galbraith P. W. (1997). Washington, Erdut and Dayton: Negotiating and Implementing Peace in Croatia and Bosnia Herzegovina. In: Cornell International Law Journal. Vol. 30, p. 643-649.

10. Belloni R. (2007). State building and international intervention in Bosnia. New York: Routledge, $212 \mathrm{p}$.

11. Tirpak J. A. (1997). Deliberate Force. In: AIR FORCE Magazine. Vol. 80, No. 11, p. 35-43.

12. Kijasov A. S. (2010) Politika "priznanija/nepriznanija": amerikanskie interesy na Balkanah na nachal'nom jetape jugoslavskogo krizisa (1991-1992 gg) [The "recognition / non-recognition" policy: American interests in the Balkans at the initial stage of the Yugoslav crisis (1991-1992)]. In: Scientific notes of Kazan University. Seria: Humanities. Vol. 152, book. 3, part. 1, p. 246-253. (In Russ.).

13. Bazhukov V. I. (2018) «Mirotvorcheskaja» operacija NATO v Bosnii i Gercegovine (19921995): koncepcija i real'nost' ["Peacekeeping" Operation in Bosnia and Herzegovina (1992-1995): Concept and Reality]. In: Management Consulting. No. 2, p. 34-41. (In Russ.).

14. Daalder I. H. (1998) Decision to Intervene: How the War in Bosnia Ended. In: Foreign Service Journal. Vol. 73. p. 24-31.

Received: 25.08 .2021 .

About author: Dzemyanovich Yuliya, a postgraduate student of the Department of international relations of Belarusian state University (Minsk); e-mail: yuliyadzemy@rambler.ru. 